\title{
National migration administration: modern theories as a basis for effective modernization
}

\author{
Hung Tran $\mathrm{Van}^{1}$, Huong Le Thi $\mathrm{Mai}^{2}$, and Sommaya Prachyangprecha ${ }^{3^{*}}$ \\ ${ }^{1}$ Vietnam National University of Forestry, Dong Nai Province, Vietnam \\ ${ }^{2}$ HCMC University of Technology and Education, Ho Chi Minh City, Vietnam \\ ${ }^{3}$ International College, Suan Sunandha Rajabhat University, Bangkok, Thailand
}

\begin{abstract}
Studying the key impact factors, development regularities and consequences from the international labor migration has its own solid place in Western socioeconomic sciences for the last six decades already. Throughout this whole period quite many truly original research works have been carried out in dozens of countries worldwide and unique scientific approaches have been developed so that to determine the causeeffect relations within the migration dynamics (including the theory of human capital, the theory of household optimization, the Todaro model etc.). In this article the author makes an attempt to overview the key results of the most outstanding research studies on international labor migration which have been carried since the middle of the 20th century and till now. Afterwards, the author also offers her own methodology for evaluation of migration risks from the standpoint of population in foreign countries. The author suggests to use this model in the process of developing modern migration policy at both national and regional levels.
\end{abstract}

\section{Introduction}

Empirical research of the factors determining the dynamics, structure and indicators of internal and external (international) labor migration has become widely popular in Western social and economic sciences. Such studies have been actively carried out by many world known scientists, specialized research centers at leading universities and also representatives of both regional and national-level public bodies as well as experts affiliated to various international organizations.

The availability of this huge database of empirical results obtained by scientists from very different countries (thus, under very different economic, social, political and cultural conditions) allows us to assume that there is a sufficient theoretical background for successful formulation of modern migration policy.

* Corresponding author: sommaya.pr@ssru.ac.th 


\section{Literature review}

The absolute majority of the available empirical studies on the international labor migration have been carried out stemming from the aggregated macroeconomic indicators. Besides, despite all the wide range of potential factors and causes behind international labor migration (especially taking into account that today there are quite many alternative approaches to its scientific determination), the majority of applied studies on the development of international labor migration have been concentrating on a rather obvious functional dependence between international labor migration on the one side and wage size (in both donor and recipient countries), employment opportunities and the costs of migration decision for a migrant on the other.

Results of the numerous economic studies on migration flows (carried out under the neoclassical framework or using more recent alternative visions of international labor migration) confirm that the most important precondition for making a migration decision is the factor of migrant's potential income in a destination country [1].

At the same time, results of the international labor migration studies might become less predictable if they include the variable of employment probability (as in the Todaro model). Thus, the criteria of employment probability and of the expected term of getting the first salary in a new country have proved to be highly meaningful in the cases of Tanzania [2], Venezuela [3], Kenya [4] and Columbia [5].

Back in the 1960s, social tensions in some of Western countries caused by the growth of uncontrolled internal labor migration have provoked numerous research studies on the migration from rural areas to large cities. For example, C. Bishop, as early as in 1967, proved empirically that there is a direct relation between urbanization development (and thus migration of rural population into cities) with the labor market gaps in rural areas. In that case, labor market gaps were understood as the market's inability to regulate the flows of workers, to manage the income information on the labor situation and to be overall capable to react to sectoral market changes in a timely manner [6].

G.E. Shuh came up with a once truly novel research which partially became the basis for the later Todaro model. Shuh presented the econometric data confirming that increase in the expected income in non-agricultural sectors, just like reduction of unemployment, would lead to the growing supply at the labor market in agricultural sectors [7]. The same author also revealed that the growth of incomes in agriculture (for example, due to implementation of state programs supporting a certain level of prices for agricultural commodities), just like the growth in education level among the dwellers of rural areas, would have only positive effects on migration of employable population to larger cities.

Barkley proved empirically that strict limitations imposed on labor migration in recipient countries and even growing unemployment in them turn out to be much less meaningful factors in migration decision-making as compared to market environment in donor countries or regions [8].

Of interest for us are also the research studies concerning the relation between rates and factors of the international labor migration on the one side and forms of migration (legal or illegal) on the other $[9,10,11]$.

Thus, J.C. Jenkins analyzed the dynamics of both legal and illegal migration between the USA and Mexico in the period from 1958 and 1972 to come up with the conclusion that [12] the most influential factor for migration decision-making in the case of these two countries was the indicator of employment probability. Moreover, this author proved empirically that the deeper in Mexico (farther from the border with the US) is the initial location of a migrant - the more meaningful this factor becomes in the course of decisionmaking. And even the factor of wage difference (between agrarian jobs in Mexico and industrial jobs in the US) seems to be less meaningful for migration decision-making. 
In our view, the most interesting conclusion of Jenkins (that was actually confirmed later by some other authors [13]) is that all theoretical assumptions (for example, the Todaro model and/or earlier neoclassical models of labor migration) work well mostly in the field of illegal labor migration. This conclusion has its explanation: in the field of illegal/shadow migration, all the (pre)conditions can be described as "wild market" conditions since all its agents counteracting under the conditions of ideal competition making use of almost unlimited supply and demand at the labor market.

Studies by Robert D. Emerson [14] can serve as another excellent example of using the theoretical concept of human capital for determining the expected income from migration decision. Emerson's research stemmed from the idea that long-term payoff for a sending household has its impact on the migration decision and its further implementation. Emerson analyzed quite an impressive amount of personal data on the labor migrants in agriculture of Florida and Luisiana, and later also reproduced a similar study but in Southern France already.

Progress of any national economic model should be oriented on the production factors and competitive advantages of the higher order (innovations, advanced qualifications, latest information technologies [15], including metatechnologies [16]) and also on the development of own labor resources. When such a national economic system starts to be facing cheap non-qualified labor resources in enormous quantities, it might lose additional stimuli for further innovative development. Moreover, it can quickly lose the already accumulated potential for development and may even "simplify itself" down to the level of the countries supplying labor migrants to the world labor market.

\section{Methodology}

Our idea here is to stem from the contemporary theories of human capital and their understanding of the structure and dynamics of the international labor migration and carry out a research of macroeconomic indicators of the contemporary states in the context of massive circulation of non-qualified labor migrants. Our secondary aim here is to reveal the potential threats for the national economic systems of the countries receiving foreign labor migrants.

The core assumption of our research is that in different countries with their very different levels of socioeconomic development, the indices of human capital would be also very different, primarily due to differences in labor productivity indicators, while the latter can be easily determined by statistical methods applied to the World Bank data.

According to the assumptions by the supporters of the theory of human capital as a factor of a cause of the international labor migration, a positive migration decision will be made if a carrier of human capital is confident about own future employment in a new country and also in higher wages there.

In our research here below we analyze solely massive non-qualified labor migration. Therefore, it is highly unlikely that once these labor migrants get into a new country, they would quickly improve the quality of own human capital.

It would be logical to study at least the selected countries worldwide in relation to how easy can foreign migrants in them earn "good money" working with the same rate of productivity as back at home. We can assume that if labor migrants continue working with the same levels of productivity and same quality of own human capital, they will earn less than back at home. Countries with such a labor situation for most of labor migrants would be attractive primarily for illegal migrants who are not capable/ready to socialize and develop own human capital, neither in a short, nor in a long term. Consequently, countries sending such labor migrants abroad (not directly sending but creating the conditions that are 
pushing migrants from the country) would become a real threat in terms of national economic system destabilization.

In our research we consider the macroeconomic indicators of 77 countries worldwide. We have used the World Bank statistics (publicly available at www.worldbank.org). The key results are presented in the table below.

\section{Results and discussion}

As it is clearly seen in the table, an average citizen of Norway with their average labor productivity (which is the most important component of human capital of any worker) can easily earn the same wage in nearly any country worldwide as back at home. Therefore, labor migration from Norway to, for example, France would never become a threat for the national economic system of the latter. This is primarily because the (hypothetically) arriving Norwegians are the carriers of human capital of the top quality, and this means they would have only the most positive influence on any state receiving them, primarily through high productivity of their labor in a new country.

On the other hand, an Indian citizen migrating to Turkey or Spain would hardly be able to earn more than back at home. Thus, we can conclude that the Indian is the carrier of lower (as compared to the Turks or Spaniards) human capital. Therefore, hypothetical massive inflow of Indian labor migrants into Spain or Turkey would quickly become a real threat for their economies (especially for Spain since its economy is weaker).

Table 1. Probability of migration flows and migration threats within the world economic system today (World Bank data, as of 2017).

\begin{tabular}{|c|c|c|c|c|c|}
\hline \# & $\begin{array}{l}\text { 壳 } \\
\stackrel{0}{0}\end{array}$ & 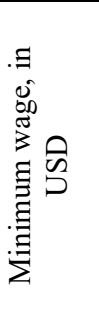 & 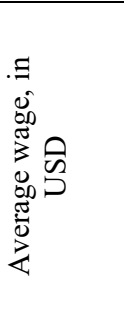 & 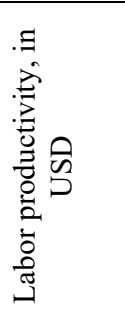 & 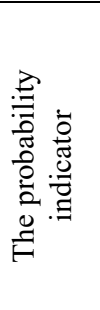 \\
\hline 1 & Zambia & 317 & 780 & 5470 & 4.98 \\
\hline 2 & Saudi Arabia & 7500 & 15108 & 73630 & 3.25 \\
\hline 3 & Norway & 16900 & 44136 & 191372 & 3.13 \\
\hline 4 & UAE & 10100 & 9840 & 60430 & 3.03 \\
\hline 5 & Venezuela & 3400 & 5160 & 24980 & 2.91 \\
\hline 6 & Australia & 20027 & 31320 & 123024 & 2.39 \\
\hline 7 & Jordan & 2450 & 5880 & 19734 & 2.36 \\
\hline 8 & Italy & 12100 & 29340 & 94737 & 2.28 \\
\hline 9 & Uruguay & 3000 & 9660 & 28632 & 2.26 \\
\hline 70 & Ukraine & 1661 & 7800 & 7612 & 0.8 \\
\hline 71 & Vietnam & 1000 & 2040 & 2423 & 0.79 \\
\hline 72 & Macedonia & 4300 & 16140 & 15575 & 0.76 \\
\hline 73 & Kyrgyzstan & 251 & 3540 & 2738 & 0.72 \\
\hline 74 & Morocco & 2650 & 12960 & 9521 & 0.6 \\
\hline 75 & Bangladesh & 798 & 1884 & 1580 & 0.58 \\
\hline 76 & Bolivia & 2904 & 6480 & 5162 & 0.55 \\
\hline 77 & Ghana & 698 & 6720 & 3944 & 0.53 \\
\hline
\end{tabular}


Several contradictory/suspicious observations presented in this table above would probably require additional commenting. For example, such an impressive result of Zambia can be explained by not only high labor productivity in this country but also by extremely low (as compared to high productivity) wages in it. In other words, a citizen of Zambia can migrate to literary any other country of the world and earn much more than back at home, working with roughly the same rate of labor productivity. For example, for the same amount and quality of work a Zambian can get 780 USD (per annum) back at home - or 3000-4000 USD per annum on a new job in South Africa.

Among these leaders we can also mention Venezuela. Obviously, this country got to the top of this list not due to high labor productivity but rather due to very low wages. This means that a migrating Venezuelan would be able to earn much more (working with the same productivity) in quite many countries worldwide (for example, 4 times more in South Africa, nearly twice more in Brazil and so on).

If we compare two super-states (from the standpoint of national population numbers) India and China, we can note that the destabilizing threat of Chinese migration to India is much higher than in the opposite direction.

Outsider positions of Thailand and South Korea can be explained by the fact that in both these countries labor productivity has been lowered rather artificially (by means of various social programmes that are aimed at maintaining zero unemployment and creation of extra employment opportunities in these countries).

Finally, Bangladesh. This is the state with extremely low labor productivity but relatively high salaries at the same time (as compared to some other Asian countries and especially if compared with its labor productivity indicator). An average Bangladeshi as the carrier of minimal human capital would hardly be able to find a country where he/she can earn more than back at home. This makes thousands of Bangladesh citizens become potential participants of illegal migration, thus also becoming the destabilizing factor for national economic systems of the countries receiving them (neighbouring India in the first place). This trend becomes especially threatening considering the rapidly growing population of Bangladesh.

\section{Conclusions}

Basing on the offered here methodology of migration threats' assessment and also of the potential consequences of non-regulated development of the international labor migration, we can now outline several fundamental provisions concerning modernization of national migration policies, at both national and regional levels.

First and foremost, the key feature of a future migration policy must be its two-vector nature, that is, being directed on both internal and external strategic goals at the same time.

In part of internal strategic goals we can mention the methods of state regulation and also maintaining the balance within the national economic system. State authorities are expected to limit the too quick growth of those sectors that are actively using non-qualified labor of foreign migrants.

The state is also expected to regulate the capital inflows so that too much of national capital would not go into labor-intensive sectors which are not requiring well developed skills. In other words, the state is expected to limit the external supply of non-qualified migrating labor force which is trying to enter the national labor market. In such a way, the state would be able to maintain the overall national competitiveness and gradually implement the national strategy of further economic growth (ideally - through development of competitive advantages of the higher order). 
The second important direction in the development of a national migration policy must be oriented on the migrants themselves, this includes the migrating workers as well as other members of their families (households).

Here, state authorities should take into account the migrants' readiness to spend around $10-20 \%$ of their earnings on getting additional education and retraining themselves so that to get higher qualification and better job. In such a context, it would be quite logical to introduce separate social programmes (within the national migration policy) aimed at active development of education and trainings for foreign migrants in Russia which would be sponsored by migrants themselves or through the programmes of preferential crediting of educational services.

Partially, such programmes can be covered through specialized funds. This can be a Foundation for Social Support of Migrants (FSSM): employees can transfer part of the taxes they pay from migrants' work; finally, fines paid by the migrants for violations of migration-related legislation can be also directed to this fund (in full or a certain share of a fine).

To sum up, we would like to offer the following key principles for future implementation of a national migration policy:

- active use of bilateral agreements (with a separate country or a group of countries, such as the EU);

- dynamic nature of changes in national migration policy (requirements to labor migration should be revised from time to time, taking into account the situation at the labor market);

- regular assessment of migration threats;

- mutual responsibility of the countries that have signed bilateral agreements;

- coordination of migration and border policies with the countries that have signed bilateral agreements;

- moderately discriminatory nature of the national migration policy;

- migration control can be dispersed territorially (some of its functions can be actually moved to the pre-migration stage and thus be carried out on the territory of a donor country).

Implementation of these and some other principles would help with increasing the overall efficiency of the national migration policy, and this, in turn, would eventually make migration policy a powerful instrument to be applied in such spheres as world trade, global investments, geopolitical relations, diplomacy and more.

\section{References}

1. L. Yap, J. of Development Economics 4, 26 (1977).

2. H. Barnum, R. Sabot, Education, Employment Probabilities and Rural-Urban Migration in Tanzania (World Congress Econometric Society, 1975).

3. M. Levy, W. Wadycki, Econometrica 42(2), 377 (1974).

4. H. Rempel, R. Lobdell, J. of Development Studies 14, 324 (1978).

5. W. Falaris, Population and Development Review 5 (1987).

6. C. Bishop, Farm Labor in the United States (Columbia University Press, New York, 1967)

7. G. Schuh, J. of Farm Economics 44, 307 (1962).

8. A. Barkley, American J. of Agricultural Economics 72(3), 567 (1990).

9. D. Ushakov, E. Rubinskaya, Political and Economic Climate: Breakthroughs in research and practice 2, 625 (2018). 
10. A.Tran, N. Minh, D. Ushakov, Int. J. of Recent Technology and Engineering 8,2S11. 3883 (2019).

11. H. Mai, H. Van, D. Ushakov, Int. J. of Recent Technology and Engineering 8,2S11. 3876. (2019).

12. J. Jenkins, International Migration Review 11, 178 (1977).

13. M. Blejer, H. Johnson, A. Prozecanski, Research in Population Economics 1, 217 (1978).

14. R. Emerson, American Journal of Agricultural Economics 71(3), 617 (1989).

15. M. Porter, Competitive advantage: Creating and sustaining superior performance: with a new introduction (New York, Free Press, 1998).

16. M. Delyagin, The World Crisis. The General Theory of Globalization (Moscow, 2003) 